\title{
PENDIDIKAN MEDIA LITERACY PADA SISWA/SISWI SMPN 10 PADANG
}

\author{
Alna Hanana, Yesi Pupita, Revi Marta, dan Novi Elian \\ Jurusan Ilmu Komunikasi FISIP Universitas Andalas \\ Email: alna.hanana@gmail.com
}

\begin{abstract}
ABSTRAK
Dewasa ini, internet telah tumbuh menjadi sedemikian besar dan berdaya sebagai alat informasi dan komunikasi yang tak dapat diabaikan. Penggunanya kini mencakup berbagai kalangan. Perkembangan teknologi komunikasi dan cyber media sudah selayaknya diimbangi dengan kemampuan melek bermedia masyarakat, termasuk anak-anak yang merupakan konsumen aktif dunia maya. Kegiatan pengabdian masyarakat ini dilatar belakangi oleh masih kurangnya kemampuan melek media internet pada masyarakat di Sumatera Barat terutama bagi siswa siswi SMP yang saat ini rata-rata sudah sangat aktif mengkonsumsi media sosial dengan tujuan memberikan edukasi untuk bisa bijaksana dalam menggunakan internet. Sasaran utama dalam kegiatan ini adalah siswa-siswi SMPN 10 Padang dengan jumlah peserta sebanyak 30 orang. Metode kegiatan dilakukan secara sistematis yaitu dengan berupa presentasi, diskusi kelompok, tanya jawab dan evaluasi dalam bentuk kuis/games. Kegiatan pengabdian masyarakat di SMPN 10 Padang ini telah berjalan dengan lancar dan sesuai dengan rencana yang ditetapkan. Hasil kegiatan ini pengabdian ini menunjukkan bahwa anakanak peserta kegiatan mulai memahami bahwa bahaya internet tidak hanya sebatas bahaya fisik tetapi juga sampai pada bahaya keamanan psikologis dan bahkan hukum, sehingga mereka berjanji untuk lebih bijak menggunakan internet ke depannya. Artinya, peserta sudah berhasil memahami apa itu literasi media dan bagaimana cara menggunakan media dengan lebih bijak.
\end{abstract}

Kata Kunci: Pendidikan, Literasi media, Anak

\section{PENDAHULUAN}

\section{Analisa Situasi}

Kegiatan pengabdian masyarakat ini dilatar belakangi oleh masih kurangnya kemampuan melek media internet pada masyarakat di Sumatera Barat terutama bagi siswa siswi SMP yang saat ini rata-rata sudah sangat aktif mengkonsumsi media sosial. Kemampuan melek media adalah hal yang sangat penting dimiliki, tetapi hingga saat ini masih belum termasuk ke dalam materi pendidikan resmi yang diberikan di sekolahsekolah. Oleh karena itu, tim pengabdian ini mengadakan pendidikan media literacy untuk anak-anak dengan mendatangi langsung sekolah mereka.
Dewasa ini, internet telah tumbuh menjadi sedemikian besar dan berdaya sebagai alat informasi dan komunikasi yang tak dapat diabaikan. Penggunanya kini mencakup berbagai kalangan. Alasan penggunaannya pun beraneka ragam, mulai sekedar untuk berkomunikasi hingga mengakses informasi dan data yang penting. Media internet didefinisikan sebagai jaringan luas komputer yang dengan perizinan dapat saling berkoneksi antara satu dengan yang lainnya untuk menyebarluaskan dan membagikan digital files, serta memperpendek jarak antar negara. Media internet memiliki berbagai macam teknologi, seperti website, transfer file, email, jaringan 


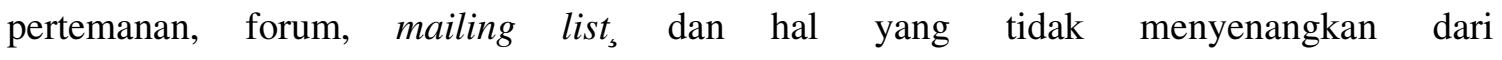
sebagainya (Yunus, 2011).

Hasil survey Asosiasi Penyelenggara kemudahan mengakses Internet ini yang Jasa Internet Indonesia (APJJ) tahun 2016 melaporkan bahwa 256,2 juta orang di Indonesia, lebih dari setengahnya menggunakan internet, yaitu 132,7 juta jiwa. Angka pengguna internet tersebut mengalami pertumbuhan 51,8 persen dari survei APJII 2014 dengan mencatat 88 juta pengguna. Pengguna internet dengan karakteristik usia anak-anak (rentang usia 10-14 tahun) adalah sebanyak 768 ribu. Dengan perkembangan teknologi komunikasi dan cyber media sudah selayaknya diimbangi dengan kemampuan melek bermedia masyarakat.

Selain itu, menurut lembaga riset MarkPlus Insight, mereka yang merupakan netizen atau pengguna Internet yang sehariharinya menghabiskan waktu lebih dari tiga jam dalam dunia maya meningkat dari 24,2 juta pada 2012 menjadi 31,7 juta orang pada 2013 (Marketeers, 2013). Berdasarkan hasil riset MarkPlus Insight tersebut dinyatakan pula bahwa separuh dari netizen di Indonesia merupakan pengguna Internet muda berusia di bawah 30 tahun dan bahkan hampir 95\% dari netizen adalah pengguna Internet melalui perangkat ponsel atau smartphone (Marketeers, 2013). Internet yang saat ini dengan mudahnya diakses melalui ponsel cerdas atau smartphone sering kali membuat seseorang menjadi ketagihan sehingga tidak mengenal waktu untuk mengaksesnya. Halmenjadikan media literasi menjadi suatu hal yang penting. Karena mau tidak mau, pengakses berita yang harus diedukasi untuk dapat memanfaatkan Internet dengan baik.

Pendidikan melek media atau media literasi merupakan hal yang penting diberikan kepada anak-anak. Usia siswa dan siswi SMP (12 hingga 15 tahun) merupakan usia rentan bagi anak-anak. Dimana pada fase ini anakanak sudah bisa menggunakan cyber sendiri dengan pengawasan yang longgar dari orang tua. Kebutuhan sekolah yang sudah mulai aktif memanfaatkan internet, mengakibatkan anak-anak lebih aktif menggunakan internet. Rasa ingin tahu anak-anak, mengakibatkan keinginan mereka mengakses internet lebih intens. Oleh karena itu, penting bagi anakanak usia 12- 15 tahun mendapatkan pendidikan media literasi.

\section{Perumusan Masalah}

Sampai saat ini instansi pendidikan di Sumatera Barat khususnya pelajar SMPN 10 Padang belum banyak dikenalkan serta mendapatkan pengetahuan tentang dunia komunikasi terutama pendidikan media literacy. Sementara kemampuan literasi media sangat diperlukan agar tidak menjadi korban dari globalisasi. Kemampuan literasi media belum dimiliki oleh siswa-siswi di SMP ini dikarenakan pendidikan ini memang tidak ada dalam kurikulum sekolah. Padahal para pelajar yang ada disini khususnya siswa- 
siswi SMP sudah sangat terpapar dan banyak mengkonsumsi media maya. Penggunaan dan kepemilikan smartphone sudah bukan hal baru dan langka lagi bagi siswa-siswi sekolah menengah.

Karenanya pendidikan literasi media kepada siswa-siswi khususnya pelajar SMP ini perlu dilakukan, apalagi memang sekolah ini sangat dekat dengan kampus Universitas Andalas sehingga seharusnya bisa merasakan manfaat langsung perkembangan pengetahuan. Pendidikan media literasi merupakan salah satu solusi untuk mengantisipasi berbagai dampak buruk internet pada anak sebagai bagian dari masalah media dan komunikasi saat ini, tentu diperlukan data bagaimana keadaan masyarakat yang sebenarnya. Kegiatan pengabdian ini bisa menjadi sebuah gambaran dan referensi ilmiah bagi masyarakat maupun pemerintah tentang pentingnya literasi media terutama pada anak-anak di bangku sekolah.

Pelatihan ini akan membawa kesadaran bagi siswa-siswi di SMP tersebut dan kedepannya nanti pelajar-pelajar SMP tersebut tidak buta lagi akan dunia informasi dan komunikasi khususnya literasi media. Sebab ilmu ini akan bermanfaat bagi mereka kedepannya serta melindungi mereka dari berbagai kejahatan dan dampak negatif dunia maya.

\section{Tinjauan Pustaka}

Istilah literasi media diciptakan di mid2004 untuk menggabungkan literasi lainnya dengan visual (Ofcom, 2004). Ofcom mengatakan literasi adalah keterampilan untuk mengakses, menganalisa, mengevaluasi dan sekaligus mengkomunikasikannya dalam berbagai macam format. Lebih daripada itu adalah mampu mengenali dan mengerti informasi secara komprehensif untuk mewujudkan cara berpikir kritis, seperti tanya jawab, menganalisa dan mengevaluasi informasi itu. Potter (2005) mengatakan bahwa literasi media adalah sebuah perspekif yang digunakan secara aktif ketika, individu mengakses media dengan tujuan untuk memaknai pesan yang disampaikan oleh media.

Secara sederhana media literasi adalah kemampuan untuk memilah, mengakses, dan menganalisis isi media. Kemampuan ini harus dimiliki semua orang untuk dapat menjadi seorang penonton yang cerdas dan terhindar dari kepentingan-kepentingan dalam industri media. Dengan menguasasi informasi akan memungkinkan seseorang untuk menguasai dunia. Media literasi merupakan sebuah konsep kesadaran masyarakat terhadap media. Melalui media literasi, masyarakat diajak untuk menyadari bahwa media tidak lagi hanya berperan sebagai kontrol sosial dan cermin realitas, tapi media mencoba mengkonstruksi realitas sosial secara subjektif. 
Berdasarkan hal tersebut, materi yang diberikan adalah bagaimana anak-anak dapat memanfatkan internet dengan konten yang sesuai dengan usia mereka, dan bagaimana penggunaan internet yang positif sesuai dengan usia mereka.

\section{TUJUAN DAN MANFAAT}

\section{Tujuan}

Secara garis besar media literasi dibutuhkan pelajar karena:

a. mereka hidup di lingkungan bermedia;

b. literasi media menekankan pada pemikiran kritis;

c. menjadi literat terhadap media merupakan bagian dari pembelajaran terhadap warga negara,

d. membuat dapat berperan aktif dalam lingkungan yang dipenuhi dengan media; dan

e. pendidikan media membantu dalam memahami teknologi komunikasi.

Sasaran utama dalam kegiatan ini adalah memberikan edukasi kepada anak-anak dalam menggunakan internet. Literasi media penting untuk anak agar anak tidak salah pilih media dan meminimalisir asumsi kepada hal-hal yang tidak diinginkan dan hal yang tidak patut untuk dikonsumsi oleh anak.

\section{Manfaat}

a. Siswa dan siswi mendapatkan Literasi teknologi: kemampuan untuk memanfaatkan media baru seperti internet untuk mengakses dan mengomunikasikan informasi secara efektif

b. Siswa dan siswi mendapatkan Literasi informasi: kemampuan untuk mengumpulkan, mengorganisasikan, menyaring dan mengevaluasi informasi

c. Siswa dan siswi mengetahui mafaat dan dampak negatif dari media internet.

\section{METODE PENGABDIAN}

\section{Metode Pengabdian}

Untuk menyelesaikan permasalahan yang sedang dihadapi mitra khususnya pelajarpelajar SMP untuk mendapat pendidikan media literasi maka dalam kegiatan ini dibuat metode yang sistematis yaitu berupa presentasi, diskusi kelompok, tanya jawab dan evaluasi dalam bentuk kuis/games dengan tujuan agar siswa-siswi paham dan mengerti bagaimana seharusnya kita menyaring dan menggunakan media. Ceramah/presentasi media literasi ini akan dilaksanakan dengan berbasis digital. Narasumber akan memberikan materi dibantu degan media audiovisual untuk mendukung ceramah dan meningkatkan daya tarik dan perhatian siswa dalam menerima pendidikan media literasi tersebut.

Dalam pendidikan media literasi terdapat beberapa hal yang akan disampaikan adalah pendidikan tentang teknologi yaitu bagaimana memanfaatkan teknologi dengan efektif, pendidikan informasi; yaitu bagaimana mengumpulkan mengorganisasikan, menyaring dan mengevaluasi informasi. 
Selanjutnya adalah bagaimana memanfaatkan media internet dengan baik dan menghindari dampak-dampak negatif internet.

\section{Tahapan Pelaksanaan Kegiatan}

\section{a. Tahap Persiapan}

Pada tahap persiapan ini, tim mengadakan pertemuan untuk membicarakan hal-hal penting dalam melaksanakan kegiatan pengabdian, seperti membahas kapan waktu pelaksanaan pelatihan dapat dimulai, sampai membicarakan pencarian narasumber yang kompeten, mekanisme pelaksanaan dan persiapan susunan acara.

\section{b. Survei}

Survai

dilaksanakan

setelah menyelesaikan perbincangan tahap persiapan bersama tim. Pelaksanaan survai dilaksanakan setelah ada kesepakatan dari tim, dengan khalayak sasaran berupa siswa-siswi SMP yang mengakses dan menggunakan new media dan internet, selain itu juga menetapkan sekolah atau instansi terkait yang layak untuk di jadikan tempat atau pusat pelaksanaan kegiatan ini. Pada bulan Agustus 2017 tim pelaksana kegiatan telah dapat mencari sasaran khalayak kegiatan dengan instansi terkait yaitu siswa-siswi SMPN 10 Padang setelah mengadakan perbincangan dengan pimpinan instansi terkait dalam hal ini pembicaraan langsung pada wakil kepala sekolah SMPN 10 Padang. Sehingga pada pembicaraan tim dengan pihak instansi terkait menetapkan kesiapan pelaksaanan kegiatan yaitu pada bulan November 2017.

\section{c. Khalayak Sasaran}

Dalam pelatihan ini sasaran utamanya adalah siswa-siswi SMPN 10 Padang dari berbagai kelas yang telah memanfaatkan dan mengakses teknologi, informasi, dan komunikasi dengan new media internet namun pelatihan ini dihadiri oleh siswa-siswi dari kelas 8. Dalam pelatihan ini peserta yang hadir sebanyak 30 orang siswa peserta sesuai dengan kapasitas ruang kelas tempat acara tersebut diadakan.

\section{d. Realisasi Pelaksanaan}

Bentuk kegiatan yang dilaksanakan pedidikan media literasi pada siswa dan siswi SMP Negeri 10 Padang antara lain:

\section{Pembukaan dan Perkenalan}

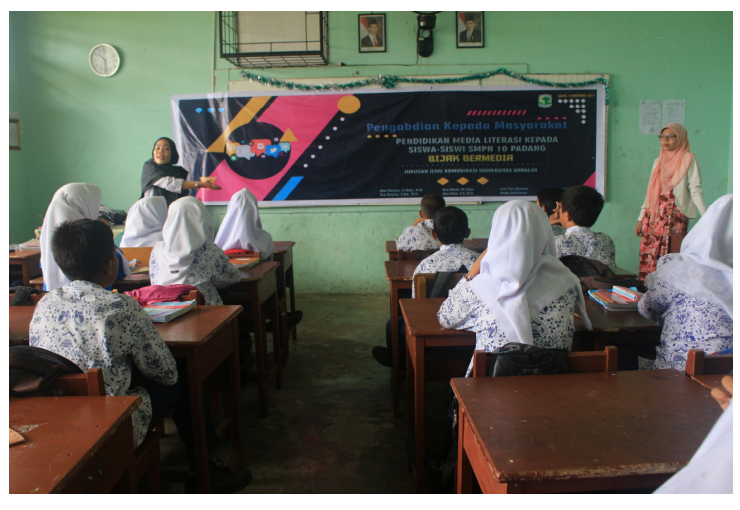

Foto 1. Pembukaan Kegiatan Pendidikan Media Literacy

Dalam rangka kegiatan pengabdian masyarakat, dilaksanakanlah pendidikan media literacy pada siswa/siswi SMPN 10 Padang. Kegiatan tersebut bermaksud untuk mengasah keterampilan dan kreatifitas siswa. Sejumlah 30 orang siswa/i SMP N 10 Padang memulai pendidikan media literasi tersebut pada hari Kamis, 9 November 2017 pukul 10.00 WIB di Ruang Kelas VIII SMP N 10 
Padang. Sebelum acara dimulai diadakan perkenalan terlebih dahulu antara pengisi acara dan peserta acara. 30 orang peserta dibagi ke dalam empat kelompok kemudian akan didampingi satu orang pementor di setiap kelompok.

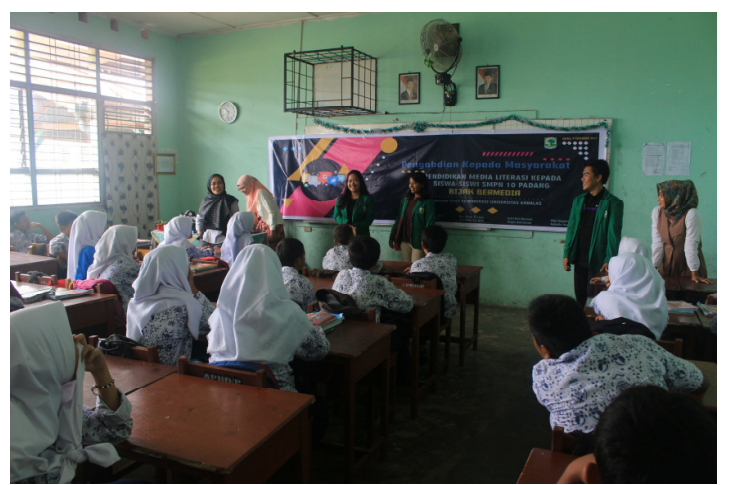

Foto 2. Pengenalan Pemateri dan Tim Pengabdian

\section{Proses Pendidikan}

Sebelum kegiatan dimulai, ada beberapa perlengkapan yang harus disiapkan diantaranya yaitu; kertas, alat tulis, laptop dan beberapa alat pelengkap lainnya. Alat tulis digunakan oleh mentor untuk membantu menerangkan. Pada kegiatan pengabdian ini, laptop juga digunakan untuk pemutaran film terkait media literasi. Hal penting lainnya yang harus disiapkan adalah contoh film yang terkait dengan literasi media itu sendiri, video ini akan menjadi contoh bagi para siswa untuk menganalisis kasus media literasi. Video ini seharusnya ditampilkan dengan fasilitas infocus didepan para siswa, tetapi karena kendala alat akhirnya ditonton dengan laptop yang digilirkan ke setiap kelompok. Setelah menonton contoh video, para siswa mendiskusikn materi yang terkait.

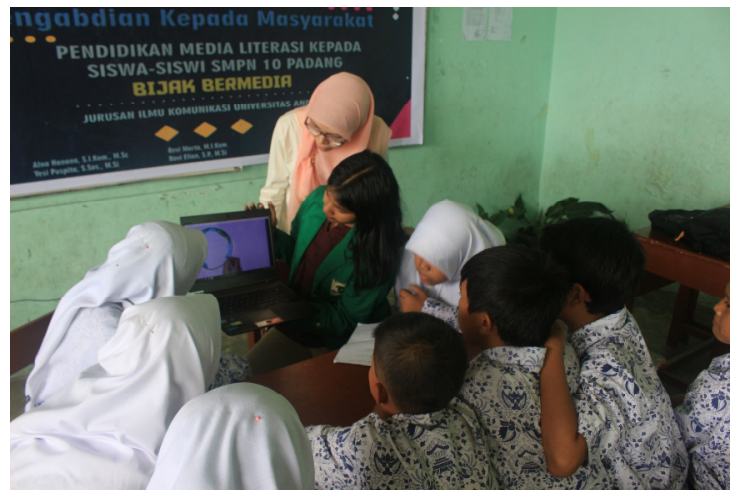

Foto 3. Menonton Film Literasi Media

Pelatihan ini dimulai dengan penjabaran tentang media sosial, seperti youtube dan instagram. Presentator menyampaikan mengenai konten-konten yang terdapat dalam youtube dan instagram. Kemudian, beberapa siswa diminta pendapatnya mengenai hal tersebut.

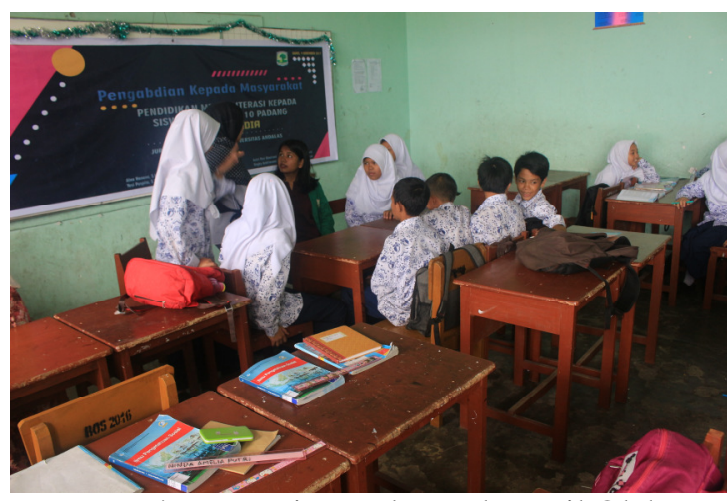

Foto 4. Mentoring Kelompok Kecil Oleh Mahasiswa

Selanjutnya siswa akan dibagi ke dalam empat kelompok dengan satu orang mentor untuk setiap kelompoknya. Lalu peserta diarahkan untuk menonton beberapa video terkait literasi media. Setelah peserta menonton video-video tersebut, mentor akan mengajak berdiskusi tentang pemakaian media mereka sehari-hari. 


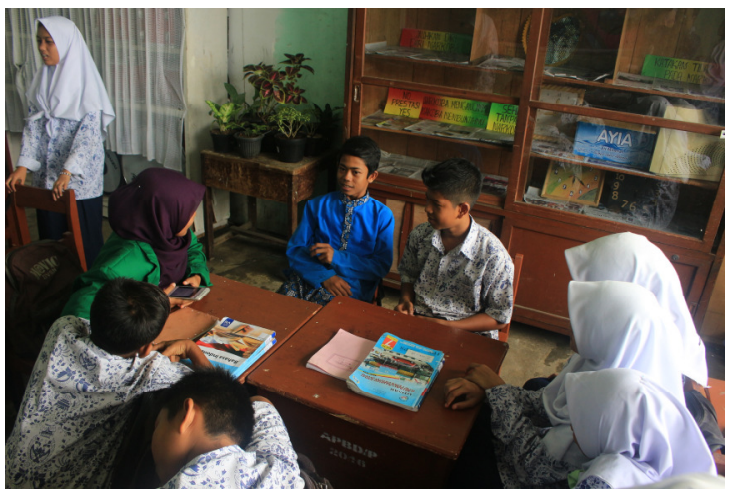

Foto 5. Mentoring Kelompok Kecil Oleh Mahasiswa

3. Evaluasi Materi

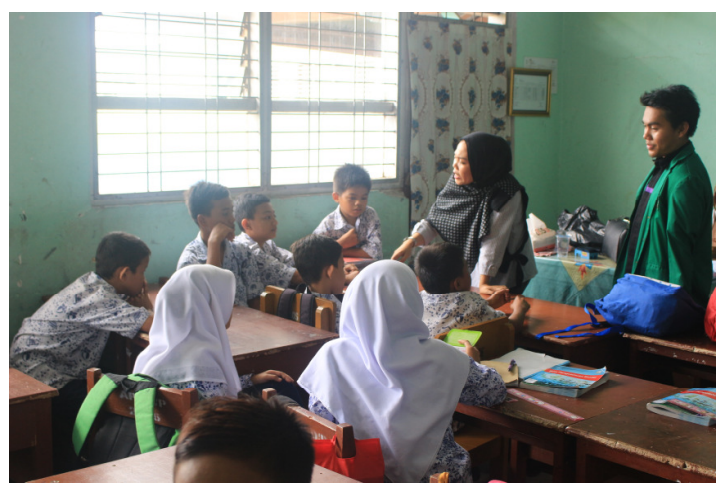

Foto 6. Evaluasi Materi Literasi Media

Setelah selesai, peserta pelatihan kembali ke tempat duduk masing-masing dan dievaluasi pemahamannya dengan media kuis/games. Masing-masing individu bisa mengikuti games karena pertanyaan lebih pada pemahaman individu. Pertanyaan kuis dan games terkait pada materi media literasi yang telah diberikan. Acara pelatihan ini pun berakhir dengan pemberian hadiah bagi pemenang games dan kuis, juga kenangkenangan dan foto bersama.

\section{Kualifikasi Tim Pelaksana}

Pelaksanaan pengabdian masyarakat ini akan dilaksanakan oleh dosen-dosen Ilmu Komunikasi Universitas Andalas yang memilik latar belakang berbagai disiplin ilmu dalam bidang jurnalistik cetak dan elektronik. Selain tim dosen kegiatan pengabdian juga dibantu oleh beberapa mahasiswa yang bertindak sebagai mentor dalam grup diskusi. Tim pelaksana terdari atas tiga orang anggota dosen, empat mahasiswa yang membantu dan satu orang ketua pelaksana.

\section{HASIL DAN PEMBAHASAN}

Kegiatan pengabdian masyarakat di SMP N 10 Padang telah berjalan dengan lancar dan sesuai dengan rencana yang ditetapkan. Secara fisik, hasil kegiatan ini pengabdian ini tidak dapat dilihat karena bentuk kegiatan ini tidak menghasilkan benda atau objek. Tujuan utama pengabdian ini adalah memberikan edukasi kepada anak-anak dalam menggunakan internet, sehingga mereka bisa mengkonsumsi media dengan bijaksana.

Kegiatan diskusi dan mentoring dalam rangkaian pengabdian ini menunjukkan bahwa pada awalnya tidak semua anak paham fungsi dari berbagai aplikasi/akun jejaring sosial. Mereka cenderung menggunakan internet untuk bermain games dan menonton video. Pemaparan peserta sejalan dengan temuan Rochmawati (2013) yang menyampaikan bahwa penggunaan internet di kalangan anak-anak internet merupakan sebuah kepentingan yang sangat dibutuhkan oleh mereka. Anak-anak lebih menyukai untuk membuka situs-situs atau alamat website yang berhubungan dengan kepentingan fun atau leisure. Mereka lebih memilih untuk membuka situs-situs yang 
berhubungan dengan musik, film dan lain sebagainya. Namun, mereka tidak paham dengan konten pesan tersirat yang mungkin terkandung dari apa yang mereka konsumsi sehari-hari.

Namun tidak berarti mereka benar-benar tidak tahu bahaya penggunaan internet. Beberapa anak paham bahwa mereka bisa terkena berbagai dampak negatif jika mengkonsumsi media maya tanpa batasan, seperti merusak mata dan mengurangi interaksi. Setelah mendengar uraian peserta, pemahaman mengenai literasi media diberikan dengan penjelasan dan pemutaran film. Mereka mulai memahami bahwa bahaya internet tidak hanya sebatas bahaya fisik tetapi juga sampai pada bahaya keamanan psikologis dan bahkan hukum, sehingga mereka berjanji untuk lebih bijak menggunakan internet ke depannya.

Anak-anak adalah end user dari produk gambar, suara, tulisan, dan simbol-simbol yang jumlahnya jutaan di internet. Jika anak tidak mempunyai filter yang baik, mereka cenderung tertarik untuk melihat hal-hal yang baru mereka ketahui tanpa paham akan apa yang dikandung oleh konten tersebut. Secara umum, pelaksanaan kegiatan ini telah berhasil mengedukasi anak-anak agar bisa bijaksana dalam mengkonsumsi media.

\section{Analisa dan Evaluasi}

Dengan campuran metode pelaksanaan berupa presentasi, diskusi, pemutaran film dan games, peserta kegiatan mengikuti semua rangkaian dengan antusias dan bersemangat. Games di penghujung kegiatan merupakan bentuk evaluasi yang dilaksanakan untuk mengukur pemahaman peserta terhadap materi yang diberikan. Hasilnya menunjukkan bahwa peserta sudah berhasil memahami apa itu literasi media dan bagaimana cara menggunakan media dengan bijak.

\section{Faktor Pendorong}

Beberapa faktor pendorong keberhasilan kegiatan ini diantaranya:

1. Materi kegiatan ini sangat dekat dengan kehidupan mereka sehari-hari, sehingga mereka mudah memahami dan mengikuti materi yang diberikan

2. Adanya pemutaran film yang bisa secara audio visual menarik perhatian dan tidak membuat bosan

3. Ketersediaan ruangan yang cukup memadai untuk terlaksananya kegiatan

4. Tanggapan positif dari pihak sekolah dan guru-guru sehingga kegiatan dilaksanakan

\section{Faktor Penghambat}

Adapun untuk faktor penghambat, secara prinsip pada dasarnya tidak ada hambatan yang berarti secara teknis pelaksanaan. Hambatan alami yang terjadi adalah suasana pelatihan yang terkadang gaduh karena teriakan dan antusiasme peserta yang berebut untuk berdiskusi ataupun menjawab pertanyaan games di akhir kegiatan.

\section{KESIMPULAN DAN SARAN}




\section{Kesimpulan}

Kegiatan pendidikan media literacy pada siswa/siswi SMP N 10 Padang dapat terlaksana dengan baik dan lancar tanpa ada hambatan yang berarti. Acara tersebut disambut dengan baik oleh pihak sekolah. Pihak sekolah sangat berterima kasih terhadap pemilihan sekolahnya dalam pelaksanaan kegiatan pengabdian masyarakat tersebut. Adapun siswa sebagai peserta pelatihan antusias menerima materi yang diberikan dan bisa mengerti serta melakukan analisis langsung tentang penggunaan media mereka sehari-hari.

\section{Saran}

a. Kegiatan pendidikan literasi media ini hendaknya dilakukan secara kontinu untuk terjangkaunya sasaran khalayak yang lebih luas dengan jumlah peserta yang lebih banyak.

b. Kegiatan pendidikan literasi media ini diperluas ke setiap tingkatan pendidikan, mulai dari sekolah dasar hingga menengah atas.

c. Guru dan orang tua agar bisa lebih meningkatkan literasi mereka sehingga mereka tidak abai dan bisa lebih memantau perilaku konsumsi media anak.

\section{DAFTAR PUSTAKA}

Astuti, Sandi Indra. 2005. Mendidik Masyarakat Cerdas Di Era Informasi. Dalam Jurnal Etos, Volume I/Th.I/2005.

Baran, Stanley J. 2003. Introduction to Mass Communication: Media Literacy and Culture (3rd edition). New York: McGraw-Hill.

Fardiah, Dedeh. 2009. Hegemoni Pasar Tayangan Anak-anak di Televisi. Unpad Press: Bandung.

Lie, Anita. Media, Sentra ke 4 Pendidikan (artikel dalam HU Kompas edisi Selasa, 7 September 2004, hal. 4-5).

Livingstone, Sonia. The Changing Nature and Uses of Media Literacy. Diakses dari

www.lse.ac.uk/collections/media@1se /mediaWorkingPaper/ewpNumber4.

Lull, James, 2011. Media, Komunikasi, Kebudayaan: Suatu Pendekatan Global. Jakarta: Yayasan Obor Indonesia.

Potter, W. James. 2004. Theory of Media Literacy: A Cognitive Approach. London: Sage Publication.

Prihandini, Isti. 2007. Pelajaran Media Literacy dan Kemampuan Melek Media. Jurnal Thesis Departemen Ilmu Komunikasi FISIP Univesitas Indonesia Volume VI/No.3 September-Desember 2007 